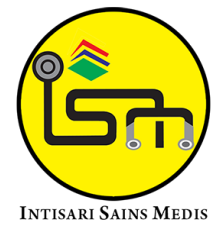

Published by Intisari Sains Medis

\title{
Alat ukur untuk menilai kemampuan fungsional pasien dengan osteoartritis lutut: tinjauan pustaka
}

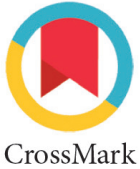

\author{
Sayu Aryantari Putri Thanaya ${ }^{1 *}$, Stanisela Agatha ${ }^{2}$, Luh Putu Ratna Sundari ${ }^{3}$
}

\section{ABSTRACT}

Background: Osteoarthritis is a common disease that has become one of the main causes of disability and is ranked fourth as a contributing factor of disability. In Indonesia, many healthcare professionals, including physiotherapists, treat patients with various stages of osteoarthritis. Physiotherapists have a crucial role in improving the functional ability of patients with knee osteoarthritis. However, many of them do not use appropriate outcome measures to document patients' improvements.

Objective: This literature review aimed to summarize the available outcome measures that can be used to measure the functional ability of patients with knee osteoarthritis, in order to increase the awareness and knowledge of healthcare professionals, particularly physiotherapists, regarding the use of available outcome measures.

Methods: The method used was literature review. Literature search was conducted in PubMed and Google Scholar databases using the main keywords: "outcome measure", "scale", "questionnaire", "knee", "osteoarthritis", "functional ability", "validity" and "reliability".

Result: This review identified 7 outcome measures in the form of questionnaires that can be used to measure the functional ability of patients with knee osteoarthritis. The most commonly used measure is the Western Ontario and McMaster University osteoarthritis index, which has been translated and validated in various languages. All measuring instruments were established in developed countries, except for the Ibadan Knee Osteoarthritis Outcome Measure. None of the 7 outcome measures have been translated and validated into Indonesian.

Conclusion: This literature review has summarized measuring tools that can be used to measure the functional ability of patients with knee osteoarthritis. To date, no tools have been translated and validated into Indonesian. In the future, it is hoped that further research can be conducted in the form of cross-cultural adaptations studies on the validity and reliability of these outcome measures into Indonesian to support the effectiveness of using these measures to assess the functional ability of patients with knee osteoarthritis.

Keywords: Outcome Measure, Functional Ability, Knee, Osteoarthritis.

Cite This Article: Thanaya, S.A.P., Agatha, S., Sundari, L.P.R. 2021. Alat ukur untuk menilai kemampuan fungsional pasien dengan osteoartritis lutut: tinjauan pustaka. Intisari Sains Medis 12(2): 415-420. D0I: 10.15562/ism. v12i2.1025

'Departemen Fisioterapi, Fakultas Kedokteran, Universitas Udayana, Bali, Indonesia;

${ }^{2}$ Program Studi Sarjana Fisioterapi dan Profesi Fisioterapi, Fakultas Kedokteran, Universitas Udayana, Bali, Indonesia;

${ }^{3}$ Departemen Ilmu Faal, Fakultas Kedokteran, Universitas Udayana, Bali, Indonesia.

\section{*Korespondensi:}

Sayu Aryantari Putri Thanaya;

Departemen Fisioterapi, Fakultas Kedokteran, Universitas Udayana, Bali, Indonesia;

sayuthanaya@unud.ac.id

Diterima: 09-04-2021

Disetujui: 15-06-2021

Diterbitkan: 21-06-2021

\section{ABSTRAK}

Latar belakang: Osteoartritis merupakan penyakit umum yang menjadi salah satu penyebab utama kecacatan dan menempati urutan keempat untuk faktor penyebab kecacatan. Di Indonesia, banyak tenaga kesehatan, termasuk fisioterapis, yang merawat pasien dengan bebagai stadium osteoartritis. Fisioterapis sangat berperan dalam meningkatkan aspek fungsional pasien dengan osteoartritis lutut. Namun, banyak yang masih belum menggunakan alat ukur yang sesuai untuk mendokumentasikan kemajuan pasien.

Tujuan: Tujuan tinjauan pustaka ini adalah untuk merangkum alat ukur yang dapat digunakan untuk mengukur kemampuan fungsional pasien dengan osteoartritis lutut, guna meningkatkan pengetahuan dan kesadaran tenaga kesehatan, terutama fisioterapis, dalam penggunaan alat ukur yang tersedia.

Metode: Metode penelitian yang digunakan adalah tinjauan pustaka. Penelusuran artikel dilakukan pada database PubMed dan Google Scholar dengan kata kunci utama: "outcome measure", "scale", "questionnaire", "knee", "osteoarthritis", "validity" dan "reliability".

Hasil: Tinjauan pustaka ini menemukan 7 alat ukur dalam bentuk kuisioner yang dapat digunakan untuk mengukur kemampuan fungsional pasien dengan osteoartritis lutut. Alat ukur yang paling sering digunakan adalah Western Ontario and 
McMaster University osteoarthritis index, yang sudah diterjemahkan dan divalidasi ke dalam berbagai bahasa. Semua instrumen pengukuran dibuat oleh negara maju, kecuali Ibadan Knee Osteoarthritis Outcome Measure. Dari 7 kuisioner, belum ada yang diterjemahkan dan divalidasi ke dalam Bahasa Indonesia.

Kesimpulan: Tinjauan pustaka ini telah merangkum alat ukur yang dapat digunakan untuk mengukur kemampuan fungsional pasien dengan osteoartritis lutut. Sampai saat ini, belum ada kuisioner yang sudah diterjemahkan dan divalidasi ke dalam bahasa Indonesia. Diharapkan adanya pengembangan penelitian berupa studi adaptasi lintas budaya terhadap validitas dan realibilitas kuisioner lainnya ke dalam bahasa Indonesia untuk menunjang efektivitas penggunaan alat ukur dalam menilai kemampuan fungsional pasien dengan osteoartritis lutut.

Kata kunci: Alat Ukur, Kemampuan Fungsional, Lutut, Osteoartritis.

Sitasi Artikel ini: Thanaya, S.A.P., Agatha, S., Sundari, L.P.R. 2021. Alat ukur untuk menilai kemampuan fungsional pasien dengan osteoartritis lutut: tinjauan pustaka. Intisari Sains Medis 12(2): 415-420. Dol: 10.15562/ism. v12i2.1025

\section{PENDAHULUAN}

Osteoartritis $(\mathrm{OA})$ adalah penyakit sendi degeneratif kronis, progresif lambat, yang mempengaruhi tulang rawan artikular dan disertai rasa sakit, bengkak, dan kehilangan fungsi. ${ }^{1}$ OA merupakan penyakit umum yang menjadi salah satu penyebab utama kecacatan ${ }^{2}$ dan menempati urutan keempat untuk faktor penyebab kecacatan. ${ }^{3} \mathrm{OA}$ dialami oleh $15 \%$ dari populasi dunia dan biasanya terjadi pada sendi penopang tubuh seperti lutut. ${ }^{4}$ Prevalensi OA lutut terstandar usia global adalah $3,8 \%$ dan OA pinggul $0,85 \%$, dan prevalensi OA lebih tinggi pada wanita dibandingkan pria. Terjadi peningkatan Year Lived with Disability (YLD) untuk OA lutut dan pinggul dari 10,5 juta pada tahun 1990 (0,42\% dari total DALY) menjadi 17,1 juta pada tahun 2010 (0,69\% dari total DALY). ${ }^{5}$ Menurut data Community Oriented for Control of Rheumatic Disorders (COPCORD), prevalensi OA lutut di wilayah Asia berkisar antara 1,4\% di perkotaan Filipina hingga 19,3\% di masyarakat pedesaan di Iran. ${ }^{6}$ Prevalensi penyakit sendi di Indonesia berdasarkan data dari RISKESDAS 2018 tercatat sekitar $7,3 \%$.

Di Indonesia, banyak tenaga kesehatan yang merawat pasien dengan bebagai stadium OA lutut. Penyedia layanan kesehatan perlu melakukan pengukuran hasil kesehatan untuk mengetahui kualitas pelayanan kesehatan dan menentukan pengambilan keputusan klinis. Penilaian hasil kesehatan merupakan proses pengukuran dimana konsekuensi penyakit dan intervensi manajemen kesehatan dinilai. ${ }^{7}$ Semua elemen yang terlibat di dalam proses pelayanan kesehatan baik itu tenaga kesehatan, pasien maupun masyarakat dapat menilai hasil akhir dari perawatan dan pengaruhnya terhadap kesehatan pasien dan masyarakat. Oleh sebab itu, penggunaan alat ukur yang tepat dan sesuai sangat penting dalam mendokumentasikan perkembangan hasil dari perawatan pasien dengan OA lutut.

Perawatan jangka panjang berkaitan dengan pengukuran kemampuan fungsional individu karena kemampuan fungsional merupakan faktor kunci dalam menentukan kualitas hidup individu serta berkorelasi dengan kesehatan fisik dan mental. ${ }^{8}$ Kemampuan fungsional dapat didefinisikan sebagai kapasitas individu untuk melakukan kegiatan dan tugas yang biasanya diharapkan. Fungsi yang diberikan mengintegrasikan domain biologis, psikologis dan sosial. ${ }^{8}$

Terdapat banyak alat ukur yang dapat digunakan untuk menilai fungsional pasien dengan OA lutut, beberapa diantaranya adalah Western Ontario and McMaster University (WOMAC), Knee Osteoartritis Outcome Score (KOOS), Ibadan Knee Osteoartritis Outcome Measure (IKHOAM) dan Community Balance and Mobility Scale (CBM). Namun, banyak tenaga kesehatan, terutama fisioterapis, yang masih belum menggunakan alat ukur yang sesuai untuk mendokumentasikan kemajuan pasien, padahal fisioterapis sangat berperan dalam meningkatkan aspek fungsional pasien dengan OA lutut. Demi tercapainya pengukuran yang tepat dan akurat, tenaga kesehatan harus memiliki pengetahuan yang memadai. Oleh karena itu, tinjauan pustaka ini dibuat untuk merangkum alat ukur untuk menilai fungsional pasien dengan OA lutut, guna meningkatkan pengetahuan dan kesadaran tenaga kesehatan, terutama fisioterapis, dalam menggunakan alat ukur yang tersedia.

\section{METODE}

Metode penelitian yang digunakan adalah tinjauan pustaka. Penelusuran artikel dilakukan pada database PubMed dan Google Scholar dengan kata kunci utama: "outcome measure", "scale", "questionnaire", "knee", "osteoarthritis", "functional ability", "validity" dan "reliability", yang dikombinasikan menggunakan Boolean operators "OR" dan "AND". Dari semua artikel yang didapatkan dari hasil penelusuran, dipilih artikel dengan berbagai jenis studi yang sekiranya relevan dengan topik tinjauan pustaka.

\section{Arthritis Impact Measurement (AIM)}

AIM dikembangkan pada pasien dengan rheumatoid arthritis (RA) dan OA oleh Meenan dkk. ${ }^{9}$ pada tahun 1980 untuk menilai 55 item status kesehatan dengan 9 subskala, yaitu mobility (5 item), physical activity (5 item), social role (7 item), social activity (9 item), pain (5 item), dexterity (5 item), activities of daily living (5 item), anxiety (8 item), dan depression (6 item). ${ }^{10,11}$ Pada tahun 1992, AIM dikembangkan kembali dengan nama 
Tabel 1. Rangkuman alat ukur untuk kemampuan fungsional pasien dengan OA lutut

\begin{tabular}{|c|c|c|c|c|c|c|c|c|}
\hline Alat Ukur & $\begin{array}{l}\text { Penulis, } \\
\text { Tahun }\end{array}$ & $\begin{array}{l}\text { Dilengkapi } \\
\text { oleh }\end{array}$ & Reliabilitas & Validitas & $\begin{array}{l}\text { Jumlah } \\
\text { Item }\end{array}$ & $\begin{array}{c}\text { Versi } \\
\text { Bahasa } \\
\text { Indonesia }\end{array}$ & Subskala/bagian & $\begin{array}{l}\text { Waktu } \\
\text { Pengisian }\end{array}$ \\
\hline $\begin{array}{l}\text { AIMS/ } \\
\text { AIMS2 }\end{array}$ & $\begin{array}{l}\text { Meenan dkk. } \\
\text { 1980, AIMS2 } \\
1992\end{array}$ & $\begin{array}{l}\text { Pasien/self- } \\
\text { administered }\end{array}$ & $\begin{array}{l}\text { AIMS2 test-retest } \\
\text { reliability: ICC } \\
0,78-0,94\end{array}$ & $\begin{array}{l}\mathrm{r}=0,75-0,89 \\
\text { dengan HAQ, } \\
\text { SF-36 }\end{array}$ & $\begin{array}{l}\text { AIM 55, } \\
\text { AIMS2 } \\
101\end{array}$ & $\begin{array}{l}\text { Belum } \\
\text { tersedia }\end{array}$ & $\begin{array}{l}\text { AIMS: } 9 \text { subskala } \\
\text { (mobility, physical } \\
\text { activity, social role, } \\
\text { social activity, } \\
\text { pain, dexterity, } \\
\text { activities of daily } \\
\text { living, anxiety, dan } \\
\text { depression). } \\
\text { AIMS2: } 12 \\
\text { subskala (ada } \\
\text { penambahan } 3 \\
\text { subskala: arm } \\
\text { function, social } \\
\text { support, dan } \\
\text { work). }\end{array}$ & $\begin{array}{l}\text { AIMS } 15 \\
\text { menit, } \\
\text { AIMS2 20- } \\
30 \text { menit }\end{array}$ \\
\hline WOMAC & $\begin{array}{l}\text { Bellamy dkk. } \\
1982\end{array}$ & $\begin{array}{l}\text { Pasien/self- } \\
\text { administered }\end{array}$ & $\begin{array}{l}\text { Test-retest } \\
\text { reliability: pain } \\
\text { ICC } 0,65-0,98, \\
\text { stiffness ICC } 0,52- \\
0,89 \text { dan function } \\
\text { ICC } 0,71-0,96 \text {. }\end{array}$ & $\begin{array}{l}\text { Construct validity: } \\
\mathrm{r}=-0,73 \text { dengan } \\
\text { SF-36 Physical } \\
\text { Function; } \mathrm{r}=-0,67 \\
\text { dengan SF-36 } \\
\text { Bodily Pain }\end{array}$ & 24 & $\begin{array}{l}\text { Belum } \\
\text { tersedia }\end{array}$ & $\begin{array}{l}3 \text { subskala: pain, } \\
\text { stiffness dan } \\
\text { function }\end{array}$ & 12 menit \\
\hline KSSS & $\begin{array}{l}\text { Insall dkk. } \\
\text { 1989, Noble } \\
\text { dkk. } 2011\end{array}$ & $\begin{array}{l}\text { Pasien dan } \\
\text { dokter/ahli } \\
\text { bedah }\end{array}$ & $\begin{array}{l}\text { ICC } \geq 0,79 \text { pada } \\
\text { semua subskala }\end{array}$ & $\begin{array}{l}\text { Cross-sectional } \\
\text { dan longitudinal } \\
\text { validity: } \mathrm{r}=0,60- \\
0,73\end{array}$ & 34 & $\begin{array}{l}\text { Belum } \\
\text { tersedia }\end{array}$ & $\begin{array}{l}4 \text { subskala: } \\
\text { objective knee } \\
\text { indicators, patient } \\
\text { satisfaction, patient } \\
\text { expectations, } \\
\text { dan functional } \\
\text { activities }\end{array}$ & $\begin{array}{l}\text { Tidak } \\
\text { disebutkan }\end{array}$ \\
\hline KOOS & $\begin{array}{l}\text { Roos dkk. } \\
1995\end{array}$ & $\begin{array}{l}\text { Pasien/self- } \\
\text { administered }\end{array}$ & $\begin{array}{l}\text { Test-retest } \\
\text { reliability: } \\
\text { pain } \text { ICC } 0,88 ; \\
\text { symptoms ICC } \\
0,87 ; \text { activities of } \\
\text { daily living ICC } \\
0,91 \text {; sport and } \\
\text { recreation ICC } \\
0,65 ; \text { quality of life } \\
\text { ICC } 0,86\end{array}$ & $\begin{array}{l}\text { Construct validity: } \\
\mathrm{r}=0,62 \text { dengan } \\
\text { SF-36 Bodily Pain; } \\
\mathrm{r}=0,48 \text { dengan } \\
\text { SF-36 Physical } \\
\text { Function }\end{array}$ & 42 & $\begin{array}{l}\text { Belum } \\
\text { tersedia }\end{array}$ & $\begin{array}{l}5 \text { subskala: } \\
\text { pain, symptoms, } \\
\text { activities of daily } \\
\text { living, sport and } \\
\text { recreation function, } \\
\text { dan knee-related } \\
\text { quality of life }\end{array}$ & 10 menit \\
\hline OKS & $\begin{array}{l}\text { Dawson dkk. } \\
1998\end{array}$ & $\begin{array}{l}\text { Pasien/self- } \\
\text { administered }\end{array}$ & $\begin{array}{l}\text { Test-retest } \\
\text { reliability: OKS } \\
\text { overall ICC } \\
0,93 \text {; OKS pain } \\
\text { ICC } 0,91 \text {; OKS } \\
\text { function } \text { ICC } 0,92\end{array}$ & $\begin{array}{l}\text { Constuct validity: } \\
\mathrm{r}=-0,879 \text { dengan } \\
\text { ICOAP; } r=-0,849 \\
\text { dengan KOOS-PS }\end{array}$ & 12 & $\begin{array}{l}\text { Belum } \\
\text { tersedia }\end{array}$ & $\begin{array}{l}2 \text { subskala: pain } \\
\text { dan function }\end{array}$ & 5-10 menit \\
\hline $\mathrm{CBM}$ & $\begin{array}{l}\text { Howe dkk. } \\
2006\end{array}$ & $\begin{array}{l}\text { Tenaga } \\
\text { kesehatan }\end{array}$ & $\begin{array}{l}\text { Test-retest } \\
\text { reliability: ICC } \\
0,95\end{array}$ & $\begin{array}{l}\text { Convergent } \\
\text { validity: } \mathrm{r}=0,52- \\
0,74 \text { dengan BBS, } \\
\text { TUGT, single-leg } \\
\text { stance, self-selected } \\
\text { gait speed dan fast } \\
\text { gait speed }\end{array}$ & 13 & $\begin{array}{l}\text { Belum } \\
\text { tersedia }\end{array}$ & - & 20-30 menit \\
\hline IKHOAM & $\begin{array}{l}\text { Akinpelu dkk. } \\
2007\end{array}$ & $\begin{array}{l}\text { Pasien dan } \\
\text { tenaga } \\
\text { kesehatan }\end{array}$ & $\begin{array}{l}\text { Test-retest } \\
\text { reliability } \text { ICC } \\
0,94-0,99, \\
\text { intrarater } \\
\text { reliability ICC } \\
0,96 \text { dan interrater } \\
\text { reliability ICC } \\
0,60\end{array}$ & $\begin{array}{l}\text { Construct validity: } \\
\mathrm{r}=-0,32 \text { dengan } \\
\text { VAS }\end{array}$ & 33 & $\begin{array}{l}\text { Belum } \\
\text { tersedia }\end{array}$ & $\begin{array}{l}3 \text { domain: activity } \\
\text { limitations. } \\
\text { participation } \\
\text { restriction, dan } \\
\text { tes physical } \\
\text { performance }\end{array}$ & 15 menit \\
\hline
\end{tabular}

AIMS: Arthritis Impact Measurement Scales; BBS: Berg Balance Scale; CBM: Community Balance and Mobility Scale; IKHOAM: Ibadan Knee Osteoarthritis Outcome Measure; ICC: Intraclass Correlation Coefficient; HAQ: Health Assessment Questionnaire; KOOS: Knee Osteoarthritis Outcome Score; KSSS: Knee Society Scoring System; OKS: Oxford Knee Score; SF-36: Short Form 36; TUGT: Timed Up and Go Test; WOMAC: Western Ontario and McMaster University 
AIMS2 dan dibuatkan bentuk singkatnya dengan nama AIMS2-SF."11 Pada AIMS2, terdapat penambahan 3 subskala, yaitu arm function, social support, dan work dengan total 101 item. ${ }^{10,11}$ Setiap subskala berisi Guttman Scale dengan beragam pilihan respon dan masing-masing item dinilai secara terpisah tanpa bobot. Disabilitas yang lebih besar ditunjukan oleh skor yang lebih tinggi. AIM dapat di selesaikan dalam 15 menit, AIMS2 dalam 20-30 menit dan AIMS2-SF dalam 10 menit. ${ }^{12}$ Nilai test-retest reliability AIMS2 adalah ICC 0,78-0,94. ${ }^{11}$ Adapun pembahasan lebih lanjut tentang AIM terdapat pada Tabel 1.

\section{Western Ontario and McMaster University (WOMAC) OA Index}

WOMAC OA index dikembangkan oleh Bellamy dkk. pada tahun $1982 .{ }^{13}$ WOMAC adalah instrumen yang paling banyak digunakan untuk mengukur pasien dengan OA pada lutut. Kuisioner ini dapat mengevaluasi 3 subskala, yaitu pain (5 item), stiffness (2 item) dan function (17 item) yang diberi skor pada skala ordinal 5 poin, yakni 0 "none", 1 "mild", 2 "moderate" 3 "severe" dan 4 "extreme". Rentang nilai subskala pain (0-20), stiffness (0-8) dan function (0-68). Skor total didapat dengan menjumlahkan skor dari 3 subskala, dengan skor maksimum 96. Skor WOMAC yang lebih tinggi menunjukkan pain, stiffness serta functional limitation yang lebih buruk. ${ }^{10,12}$ Skor total WOMAC dapat dikategorikan menjadi 3 kelompok, yaitu low risk (skor $\leq 60)$, moderate risk (skor 60-80) dan high risk (skor $\geq 81$ ). ${ }^{14}$ Kuisioner ini dapat dilengkapi sendiri oleh pasien atau melalui interview, dan telah divalidasi untuk penggunaan secara langsung, melalui telepon, atau secara elektronik menggunakan computer atau ponsel. Waktu yang diperlukan untuk menyelesaikan WOMAC baik secara langsung maupun melalui telepon adalah sekitar 5-10 menit. ${ }^{12}$ Nilai testretest reliability untuk pain adalah ICC $=$ $0,65-0,98$, stiffness ICC $=0,52-0,89$, dan function ICC $=0,71-0,96 .{ }^{10,15}$ Pembahasan lebih lanjut tentang WOMAC OA Index terdapat pada Tabel 1.

\section{Knee Society Scoring System (KSSS)}

KSSS merupakan sistem penilaian yang dikembangkan oleh Insal dkk. ${ }^{16}$ untuk
Knee Society pada tahun 1989 untuk menilai dan mendokumentasikan kemampuan fungsional pasien sebelum dan sesudah total knee arthroplasty (TKA) akibat OA lutut. Pada awalnya, nama instrumen ini disebut Knee Society Clinical Rating System, tetapi direvisi pada tahun 2012 dengan nama Knee Society Scoring System (KSSS). ${ }^{17}$ Pada KSSS yang baru terdapat versi sebelum operasi dan pasca operasi, yang diisi oleh dokter/ ahli bedah dan pasien. Bagian objektif KSSS dilengkapi oleh dokter/ahli bedah, kemudian pasien melaporkan kepuasan, aktivitas fungsional dan harapan pada bagian yang dilengkapi oleh pasien. Desain akhir dari KSSS meliputi 4 subskala, yaitu Objective Knee Score (7 item), Satisfaction Score (5 item), Expectation Score (3 item) dan Functional Activity Score (19 item). ${ }^{18}$ Total skor yang bisa diperoleh adalah 100; skor yang semakin tinggi menunjukkan hasil yang lebih baik. ${ }^{10}$ Penilaian KSSS dijelaskan lebih lanjut pada Tabel 1.

\section{Knee injury and Osteoarthritis Outcome Score (KOOS)}

KOOS dikembangkan pada tahun 1995 oleh Roos dkk. ${ }^{19}$ Instrumen ini merupakan perpanjangan dari WOMAC OA index. Tujuan utama pengembangan KOOS adalah untuk mendokumentasikan perubahan klinis setelah cedera lutut seperti cedera ligamen lutut, robekan meniscus, lesi tulang rawan lutut, dan $\mathrm{OA}$ lutut. Kuisioner ini dapat mengevaluasi konsekuensi jangka panjang dari cedera lutut, sehingga dapat memberikan penilaian terhadap pendapat pasien mengenai masalah lutut yang dialami. ${ }^{10}$ KOOS terdiri dari 42 item dengan 5 subskala yang dicetak secara terpisah yaitu pain, symptoms, activities of daily living, sport and recreation function, dan knee-related quality of life. Setiap item dinilai pada skala ordinal 5 poin (0-4), khusus untuk setiap item. Setiap subskala diberi skor secara terpisah dari 0 "extreme problems" hingga 100 "no problems", dimana skor yang lebih tinggi menunjukkan status yang lebih baik. ${ }^{20}$ Reliabilitas KOOS adalah >0,80 pada semua subskala, kecuali pada sport and recreation function $($ ICC $=0.65) .{ }^{21}$ Untuk menyelesaikan kuisioner ini diperlukan waktu sekitar 10 menit. ${ }^{20}$ Evaluasi KOOS dijabarkan lebih mendalam pada Tabel 1 .

\section{Oxford Knee Score (OKS)}

OKS dikembangkan oleh Dawson dkk. ${ }^{22}$ pada tahun 1998 untuk mengukur hasil total knee replacement (TKR), yang terdiri dari 12 item penilaian yang membahas fungsi dan nyeri pada pasien dengan OA lutut. ${ }^{23,24}$ Terdapat 5 opsi respon jawaban dalam bentuk skala ordinal yang telah dimodifikasi dari versi sebelumnya, dimana total skor berkisar dari 0-48. Skor yang lebih tinggi menandakan hasil yang lebih baik. Waktu yang diperlukan untuk menyelesaikan kuisioner ini adalah 5-10 menit. ${ }^{24}$ Nilai internal consistency 0.87 0.93 . Nilai test-retest reliability $>0,90 .{ }^{25}$ Penilaian OKS dijelaskan secara terperinci pada Tabel 1.

\section{Community Balance and Mobility Scale (CBM)}

CBM dikembangkan pada tahun 2006 oleh Howe dkk. ${ }^{26}$ Instrumen ini awalnya dirancang untuk menilai keseimbangan dan mobilitas pada pasien dengan traumatic brain injury, kemudian dikembangan untuk menilai defisit fungsional dalam keseimbangan dinamis dan mobilitas pada pasien dengan OA lutut. ${ }^{26,27} \mathrm{CBM}$ terdiri dari 13 item tugas dengan 6 item dilakukan pada kedua sisi kanan dan kiri. Skor maksimum adalah 96, dengan skor minimum 0 ; semakin tinggi skor akhir, semakin baik kemampuan fungsional dalam keseimbangan dinamis dan mobilitas pasien. CBM mempunyai nilai concurrent validity 0,52 dengan Berg Balance Scale dan 0,74 dengan Timed up and go test, dan mempunyai excellent testretest reliability $(\mathrm{ICC}=0,95) \cdot{ }^{27}$ Pemaparan tentang CBM dijelaskan lebih lanjut pada Tabel 1.

\section{Ibadan Knee Osteoarthritis Outcome Measure (IKHOAM)}

Kuisioner ini dikembangkan di Nigeria pada tahun 2007 oleh Akinpelu dkk. ${ }^{28}$ IKHOAM digunakan untuk manajemen kondisi rematik pinggul dan lutut. ${ }^{16}$ Terdapat 3 domain pada kuisioner yaitu activity limitations (25 item) dengan skor yang dinilai berdasarkan skala ordinal 5 poin (0-4), participation restriction dengan 3 item yang dinilai menggunakan skala ordinal 4 poin (0-3), dan tes physical 
performance $\left(5\right.$ tes). ${ }^{29}$ Tes physical performance meliputi: (1) $250 \mathrm{~m}$ walk test yang dinilai pada skala ordinal 6 poin (05), (2) one leg stance test yang dinilai pada skala ordinal 6 poin (0-5), (3) stairs climbing test yang dinilai pada skala ordinal 5 poin $(0-4),(4)$ squat test yang dinilai pada skala ordinal 5 poin (0-4), dan (5) balance test yang dinilai pada skala ordinal 6 poin (05). ${ }^{29}$ Skor maksimum adalah 232. Total skor untuk pasien dengan $\mathrm{OA}$ dihitung dalam persentase sebagai skor individu/ total skor yang mungkin didapatkan (232) $\mathrm{x} 100$. Nilai test-retest reliability, intrarater reliability, dan interrater reliability untuk pasien dengan OA adalah 0,94$0,99,0,96$, dan 0,60 secara berurutan. Dibutuhkan waktu sekitar 15 menit untuk menyelesaikan IKHOAM. $^{29}$ Evaluasi IKHOAM dipaparkan lebih mendalam pada Tabel 1.

\section{PEMBAHASAN}

Studi tinjauan pustaka ini menyoroti alat ukur yang dapat digunakan dalam pengukuran kemampuan fungsional pasien dengan OA lutut. Alat ukur kemampuan fungsional yang disoroti mengintegrasikan 3 domain yaitu biologis, psikologis dan sosial, dimana pasien dengan $\mathrm{OA}$ lutut mengalami penurunan kemampuan fungsional tubuh yang akan mempengaruhi psikologis pasien, sehingga faktor sosial sangat berperan dalam membantu meningkatkan kemampuan fungsional pasien. Dimensi yang dianggap penting untuk pengukuran kemampuan fungsional pasien adalah rasa sakit, fungsi, kualitas hidup, dan tingkat aktivitas. $^{20}$

Pengujian properti psikometri pada alat ukur sangat diperlukan untuk guna menunjang efektivitas penggunaannya dalam bidang kesehatan. Unsur psikometri yang paling penting dari sebuah alat ukur adalah realibilitas dan validitas. ${ }^{29}$ Semua instrumen pengukuran yang dijabarkan pada tinjauan pustaka ini memiliki nilai validitas dan realibilitas yang memadai. Alat ukur yang paling umum digunakan pada populasi dengan OA lutut adalah WOMAC, ${ }^{20}$ yang sudah diterjemahkan dan divalidasi ke dalam berbagai bahasa. Berdasarkan Tabel 1, WOMAC mempunyai test-retest reliability yang baik hingga sangat baik, terutama pada subskala function (ICC $=0,71-0,98$ ). Selain itu, terlihat jelas bahwa OKS juga mempunyai test-retest reliability yang sangat baik (ICC $>0,90)$ dan construct validity yang baik dengan ICOAP $(r=-0,879)$ dan KOOS-PS $(r=-0,849$. Berdasarkan penerapan, OKS dapat dikerjakan dalam waktu yang relatif singkat, berbeda dengan AIMS2 dan CBM yang memerlukan waktu pengerjaan lebih lama.

Dalam mengukur kemampuan fungsional pasien dengan $\mathrm{OA}$ lutut, tenaga kesehatan di Indonesia masih menggunakan alat ukur yang telah tersedia; namun, sampai saat ini belum ada kuisioner yang secara spesifik bisa digunakan untuk menilai kemampuan fungsional pasien dengan OA lutut yang sudah diterjemahkan dan divalidasi ke dalam bahasa Indonesia. Penggunaan alat ukur yang belum diterjemahkan dan divalidasi ke dalam bahasa Indonesia dapat mempersulit proses dokumentasi kemajuan pasien dan menjadi kendala dalam pengisian kuisioner, mengingat sebagian besar kuisioner diisi oleh pasien sendiri atau bersifat self-reported. Dalam situasi ini, peran tenaga kesehatan sangat diperlukan untuk memberi pemahaman terkait pertanyaan atau pernyataan yang tersedia pada kuisioner yang tidak dimengerti oleh pasien. Namun, tidak semua kata dalam kuisioner dapat diterjemahkan dengan baik ke dalam bahasa Indonesia, sehingga memungkinkan terciptanya persepsi yang berbeda terhadap sebuah pernyataan dan pertanyaan yang terdapat pada kuisioner. Hal ini dapat berdampak pada efektivitas dan akurasi pengukuran.

Selain itu, semua instrumen pengukuran dikembangkan oleh negara maju, kecuali IKHOAM, sehingga studi adaptasi lintas budaya juga diperlukan untuk mengetahui apakah item yang terdapat dalam kuisioner relevan dengan kehidupan dan budaya dari masyarakat Indonesia. Studi adaptasi lintas budaya dan pengujian terhadap validitas dan realibilitas instrumen pengukuran ke dalam bahasa Indonesia sangat diperlukan guna menciptakan pengertian yang sama untuk setiap item kuisioner yang ada, karena hal ini dapat menunjang efektivitas penggunaan kuisioner di Indonesia.

\section{SIMPULAN}

Tinjauan pustaka ini telah merangkum alat ukur yang dapat digunakan untuk mengukur kemampuan fungsional pasien dengan OA lutut. Diharapkan tulisan ini dapat membantu meningkatkan kesadaran dan pengetahuan tenaga kesehatan terkait alat ukur yang bisa digunakan untuk mendokumentasikan kemajuan kemampuan fungsional pasien dengan OA lutut. Namun, sampai saat ini belum ada kuisioner yang sudah diterjemahkan dan divalidasi ke dalam bahasa Indonesia; maka dari itu, diharapkan adanya pengembangan penelitian berupa studi adaptasi lintas budaya terhadap validitas dan realibilitas kuisioner ke dalam bahasa Indonesia untuk menunjang proses dokumentasi kemajuan kemampuan fungsional pasien.

\section{KONFLIK KEPENTINGAN}

Tidak terdapat konflik kepentingan dalam penulisan laporan penelitian ini.

\section{PENDANAAN}

Penelitian ini dilakukan tanpa hibah, sponsor, atau sumber pendanaan lainnya.

\section{KONTRIBUSI PENULIS}

SAPT dan SA berkontribusi dalam pengonsepan, penelusuran literatur, pegumpulan dan merangkum literatur, persiapan naskah, dan pengeditan naskah. LPRS berkontribusi dalam pengonsepan, pengeditan naskah dan peninjauan versi akhir naskah.

\section{DAFTAR PUSTAKA}

1. Zhang $\mathrm{Y}$, Jordan J. Epidemiology of Osteoarthritis. Clin Geriatr Med. 2010;26(3):355-69. http://dx.doi.org/10.1016/j. rdc.2008.05.007

2. Fransen M, Bridgett L, March L, et al. The epidemiology of osteoarthritis in Asia. Int J Rheum Dis. 2011;14(2):113-21. DOI: 10.1111/j.1756-185x.2011.01608.x

3. Neogi T. The epidemiology and impact of pain in osteoarthritis. Osteoarthritis Cartilage. 2013;21(9):1145-1153. http://dx.doi. org/10.1111/j.1756-185x.2011.01608.x

4. Johnson VL, Hunter DJ. The Epidemiology of Osteoarthritis. Best Pract Res Clin Rheumatol. 2014;28(1):5-15. http://dx.doi.org/10.1016/j. berh.2014.01.004

5. Cross M, Smith E, Hoy D, et al. The global burden of hip and knee osteoarthritis: estimates 
from the Global Burden of Disease 2010 study. Ann Rheum Dis. 2014;73(7):1323-30. http:// dx.doi.org/10.1136/annrheumdis-2013-204763

6. Litwic A, Edwards MH, Dennison EM, et al. Epidemiology and burden of osteoarthritis. Br Med Bull. 2013;105:185-99. http://dx.doi. org/10.1093/bmb/lds038

7. Bellamy N. Principles of Outcome Assessment. In: Hochberg MC, Silman AJ, Smolen JS, Weinblatt ME, Weisman MH (eds) Rheumatology, 4th ed. Spain: Mosby Elsevier; 2008. $12-20$ p.

8. Kirch W. Encyclopedia of public health. New York: Springer; 2008.

9. Meenan RF, Gertman PM, Mason JH. Measuring health status in arthritis. The arthritis impact measurement scales. Arthritis Rheum. 1980;23(2):146-52. http://dx.doi. org/10.1002/art.1780230203

10. Samuel AJ, Kanimozhi D. Outcome measures used in patient with knee osteoarthritis: With special importance on functional outcome measures. Int J Health Sci (Qassim). 2019;13(1):52-60

11. Meenan RF, Mason JH, Anderson JJ, et al. AIMS2. The content and properties of a revised and expanded arthritis impact measurement scales health status questionnaire. Arthritis Rheum. 1992;35(1):1-10. http://dx.doi. org/10.1002/art.1780350102

12. Carr A. Adult measures of quality of life: The Arthritis impact measurement scales (AIMS/ AIMS2), disease repercussion Profile (DRP), EuroQoL, Nottingham health Profile (NHP), patient generated index (PGI), quality of wellbeing scale (QWB), RAQoL, short form-36 (SF-36), sickness impact Profile (SIP), SIP-RA, and World Health Organization's quality of life instruments (WHOQoL, WHOQoL-100, WHOQoL-Bref). Arthritis Care Res. 2003;15;49(S5):S113-33. https://dx.doi. org/10.1002/art.11414

13. Bellamy N, Buchanan WW, Goldsmith $\mathrm{CH}$, et al. Validation study of WOMAC: A health status instrument for measuring clinically important patient relevant outcomes to antirheumatic drug therapy in patients with osteoarthritis of the hip or knee. J Rheumatol. 1988;15(12):183340.

14. Sathiyanarayanan S, Shankar S, Padmini SK. Usefulness of WOMAC index as a screening tool for knee osteoarthritis among patients attending a rural health care center in Tamil Nadu. Int J Community Med Public Health. 2017;4(11):4290-5. http://dx.doi. org/10.18203/2394-6040.ijcmph20174846

15. Roos EM, Klässbo M, Lohmander LS. WOMAC osteoarthritis index. Reliability, validity, and responsiveness in patients with arthroscopically assessed osteoarthritis. Western Ontario and MacMaster Universities. Scand $J$ Rheumatol. 1999;28(4):210-5. http://dx.doi. org/10.1080/03009749950155562

16. Insall JN, Dorr LD, Scott RD, et al. Rationale of the knee society clinical rating system. Clin Orthop Relat Res. 1989;(248):13-4. http://dx.doi. org/10.1097/00003086-198911000-00004

17. Scuderi GR, Bourne RB, Noble PC, et al. The new Knee Society Knee Scoring System. Clin Orthop Relat Res. 2012;470(1):3-19. doi:10.1007/s11999-011-2135-0.

18. Noble PC, Scuderi GR, Brekke AC, et al. Development of a new Knee Society scoring system. Clin Orthop Relat Res. 2012;470(1):2032. http://dx.doi.org/10.1007/s11999-0112152-z

19. Roos EM, Roos HP, Lohmander LS, et al. Knee injury and osteoarthritis outcome score (KOOS) - development of a self-administered outcome measure. J Orthop Sports Phys Ther. 1998;28(2):88-96. http://dx.doi.org/10.2519/ jospt.1998.28.2.88

20. Collins NJ, Misra D, Felson DT, et al. Measures of knee function: International Knee Documentation Committee (IKDC) Subjective Knee Evaluation Form, Knee Injury and Osteoarthritis Outcome Score (KOOS), Knee Injury and Osteoarthritis Outcome Score Physical Function Short Form (KOOS-PS), Knee Outcome Survey Activities of Daily Living Scale (KOS-ADL), Lysholm Knee Scoring Scale, Oxford Knee Score (OKS), Western Ontario and McMaster Universities Osteoarthritis Index (WOMAC), Activity Rating Scale (ARS), and Tegner Activity Score (TAS). Arthritis Care Res (Hoboken). 2011;63 Suppl 11(0 11):S208-28. http://dx.doi.org/10.1002/acr.20632

21. Xie F, Li SC, Roos EM, et al. Cross-cultural adaptation and validation of Singapore English and Chinese versions of the Knee injury and Osteoarthritis Outcome Score (KOOS) in Asians with knee osteoarthritis in Singapore.
Osteoarthritis Cartilage. 2006;14(11):1098-103. http://dx.doi.org/10.1016/j.joca.2006.05.005

22. Dawson J, Fitzpatrick R, Murray D, et al. Questionnaire on the perceptions of patients about total knee replacement. J Bone Joint Surg Br. 1998;80(1):63-9. http://dx.doi. org/10.1302/0301-620x.80b1.0800063

23. Xie F, Ye H, Zhang $\mathrm{Y}$, et al. Extension from inpatients to outpatients: validity and reliability of the Oxford Knee Score in measuring health outcomes in patients with knee osteoarthritis. Int J Rheum Dis. 2011;14(2):206-10. http:// dx.doi.org/10.1111/j.1756-185x.2010.01580.x

24. Murray DW, Fitzpatrick R, Rogers K, et al. The use of the Oxford hip and knee scores. J Bone Joint Surg Br. 2007;89(8):1010-4. http://dx.doi. org/10.1302/0301-620x.89b8.19424

25. Harris KK, Dawson J, Jones LD, et al. Extending the use of PROMs in the NHS--using the Oxford Knee Score in patients undergoing non-operative management for knee osteoarthritis: a validation study. BMJ Open. 2013;3(8):e003365. http://dx.doi.org/10.1136/ bmjopen-2013-003365

26. Howe JA, Inness EL, Venturini A, et al. The community balance and mobility scale - a balance measure for individuals with traumatic brain injury. Clin Rehabil. 2006;20(10):885-95. http://dx.doi.org/10.1177/0269215506072183

27. Takacs J, Garland SJ, Carpenter MG, et al. Validity and reliability of the community balance and mobility scale in individuals with knee osteoarthritis. Phys Ther. 2014;94(6):86674. http://dx.doi.org/10.2522/ptj.20130385

28. Akinpelu AO, Odole AC, Adegoke BOA, et al. Development and initial validation of the Ibadan knee/hip osteoarthritis outcome measure. S Afr J Physiother. 2007;63(2):3-8. http://dx.doi.org/10.4102/sajp.v63i2.127

29. Odole AC, Odunaiya NA, Akinpelu AO. Ibadan knee/hip osteoarthritis outcome measure: Process of development. Ann Ib Postgrad Med. 2013;11(2):71-6.

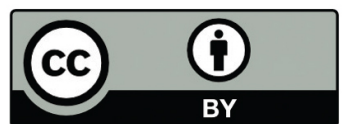

This work is licensed under a Creative Commons Attribution 